\title{
Twenty-three novel HLA-B alleles identified during intermediate-resolution testing
}

\author{
A. M. Lazaro ${ }^{1}$, K. Cao ${ }^{1}$, C. Masaberg ${ }^{1}$, N. K. Steiner ${ }^{1}$, Y. Xiao ${ }^{1}$, B. Tu $^{1}$, V. Turner ${ }^{2}$, P. Nickerson ${ }^{3}$, S. Stoll ${ }^{4}$,

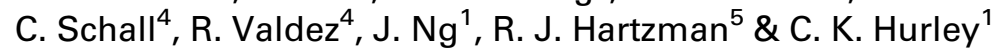 \\ 1 Departments of Oncology and Pediatrics, Georgetown University Medical Center, Washington, DC, USA \\ 2 HLA Laboratory, Pathology, MS 250 St Jude Children's Research Hospital, Memphis, TN, USA \\ 3 Canadian Blood Services, Winnipeg, Manitoba, Canada \\ 4 Histocompatibility Laboratory, University of Michigan Health System, Ann Arbor, MI, USA \\ 5 C.W. Bill Young Marrow Donor Program, Naval Medical Research Center, Rockville, MD, USA
}

\author{
Key words \\ DNA sequencing; HLA-B \\ Correspondence \\ Carolyn Katovich Hurley, PhD \\ E404 Research Building \\ Georgetown University Medical Center \\ 3970 Reservoir Road \\ NW, Washington DC 20057 \\ USA \\ Tel: 2026872157 \\ Fax: 2026876440 \\ e-mail: hurleyc@georgetown.edu
}

Received 19 June 2006; revised 6 July 2006;

accepted 9 July 2006

doi: 10.1111/j.1399-0039.2006.00661.x

\begin{abstract}
Twenty-three novel human leukocyte antigen-B alleles are described: $B * 070204$, $* 0738, * 0742, * 0821, * 130202, * 1312, * 1575, * 1598, * 1599, * 270507, * 2728$, $* 350104, * 3558, * 3811, * 3931, * 3932, * 4045, * 4107, * 420501, * 4812, * 510106$, $* 5520$, and $* 5616$. Thirteen of the variants are single-nucleotide substitutions from their most homologous allele, eight resulting in amino acid changes $(B * 0742, * 1312$, $* 1598, * 1599, * 3558, * 3931, * 4107$, and *5616) and five with silent substitutions $(\mathrm{B} * 070204, * 130202, * 270507, * 350104$, and $* 510106)$. Three alleles $(\mathrm{B} * 0738$, $* 4812$, and $* 5520$ ) differ by five nucleotide changes, altering four amino acids. The remaining seven alleles differ from their most similar alleles by two to three nucleotides, altering from one to two amino acids.
\end{abstract}

Twenty-three novel human leukocyte antigen (HLA)-B locus alleles were detected as unexpected hybridization patterns during intermediate-resolution DNA-based typing. The majority of individuals were initially typed at intermediate resolution either by a sequence-specific oligonucleotide probe bead-based technology (One Lambda LABType ${ }^{\circledR}$ ) SSO Kit (One Lambda, Canoga Park, CA, USA) or using probes designed in-house (1). Two samples were typed low resolution by sequence specific primers. The cells carrying novel alleles are listed in Table 1.

Table 2 compares the novel sequences with the sequences of the most homologous alleles. Several unique features of specific novel alleles should be noted. B*270507 introduces a new site of polymorphism, codon 161. Six new polymorphisms were found altering codons already described as polymorphic for the HLA-B locus.
Three were silent mutations ( $\mathrm{B} * 070204, * 130202$, and *510106) and three resulted in new amino acid substitutions $\left(\mathrm{B}^{*} 0742, * 1312\right.$, and $\left.* 1575\right)$. For example, codon 57 is polymorphic in HLA-B alleles, being found as three alternative codons [CCG (Pro), CGG (Arg), and CCA (Pro)]. B*070204 introduces a new codon at 57, CCT (Pro). Differing from B*0727 by five nucleotides at codons 77-83, the introduced amino acid sequence motif (NLRIALR) in $\mathrm{B}^{*} 0738$ adds the Bw4 epitope. Within the $\mathrm{B}^{* 07}$ group, the $\mathrm{Bw} 4$ epitope sequence in $\mathrm{B}^{*} 0738$ is shared only with $\mathrm{B}^{*} 0736$. Two cells were described with $B * 4812$. The sequence of exon 2 of this new allele is identical to that found in $\mathrm{B} * 4801$ but exon 3 differs by five nucleotides encodins three different amino acids. These five nucleotides are shared with $\mathrm{B}^{*} 4802$. The predicted haplotype carrying the new alleles is $\mathrm{A} * 0222, \mathrm{~B} * 4812$, 
Table 1 Cells and their the human leukocyte antigen (HLA) alleles

\begin{tabular}{|c|c|c|c|c|c|c|}
\hline Cell & Race/ethnicity & $H L A-A^{a}$ & $H L A-B^{b}$ & $\mathrm{HLA}-\mathrm{C}^{\mathrm{a}}$ & HLA-DR ${ }^{a}$ & $\begin{array}{l}\text { GenBank accession } \\
\text { Number }^{c}\end{array}$ \\
\hline GN00433 & Unknown & $A^{*} 030101,{ }^{*} 6801$ & $B * 070204, * 3503$ & $N T^{d}$ & NT & AY296125, AY296126 \\
\hline BY00054 & Caucasoid & $A^{*} 0301,{ }^{*} 2403$ & $B * \mathbf{0 7 3 8}, * 3508$ & $\mathrm{CW}^{*} 070201,{ }^{*} 0401$ & DRB1*1104,1501 & AY562130, AY562131 \\
\hline NT00571 & Caucasoid & $A * 01 T U S,{ }^{*} 24 A G V K$ & $\mathrm{~B}^{*} \mathbf{0 7 4 2},{ }^{*} 0801$ & $\mathrm{CW}^{*}$ 07BJ, ${ }^{*} 07 \mathrm{WTR}$ & $\mathrm{DRB} 1{ }^{*} 03 \mathrm{WHX},{ }^{*} 15 \mathrm{VYF}$ & DQ007037, DQ007038 \\
\hline GN00434 & Unknown & $\mathrm{A}^{*} 01 \mathrm{CRY},{ }^{*} 02 \mathrm{GNF}$ & $B *$ 0821, *0702 & $\mathrm{CW}^{*} 070201,{ }^{*} 07 \mathrm{AG}$ & DRB $1 * 04 D E X, * 1301$ & AY296127, AY296128 \\
\hline NT00574 & Caucasoid & $A^{*} 01$ WUS, ${ }^{*} 3001$ & $B * 130202, * 5701$ & $\mathrm{CW}^{*} 0602, * 06 \mathrm{BG}$ & DRB $1 *$ 07YRE & DQ007041, DQ007042 \\
\hline NT00629 & Caucasoid & A*02ANNS, ${ }^{*} 3001$ & $\begin{array}{l}B * \mathbf{1 3 0 2 0 2} \\
* 15010101\end{array}$ & $\mathrm{CW}^{*} 03 \mathrm{FJC},{ }^{*} 06 \mathrm{AJB}$ & 04NJV, 07APA & DQ334731, DQ334732 \\
\hline GN00416 & Unknown & $A * 02, * 3401$ & $B * 1312, * 380202$ & $\begin{array}{l}\mathrm{CW} \text { *0403, } \\
{ }^{*} 07020101 / 02 / 03\end{array}$ & NT & AY428806, AY428807 \\
\hline GN00425 & Unknown & $A * 30, * 33$ & $B * 1575, * 440302$ & NT & NT & AY178185, AY178186 \\
\hline GN00427 & Unknown & $A * 30$ & $B * 1575, * 1302$ & NT & NT & AY178189, AY178190 \\
\hline NT00523 & $\begin{array}{l}\text { African- } \\
\text { American }\end{array}$ & $\mathrm{A}^{*} 02 \mathrm{YAH}^{*}{ }^{*} 30 \mathrm{GSH}$ & $B * 1598, * 510101$ & $\mathrm{CW}^{*} 0202,{ }^{*} 02 \mathrm{BD}$ & DRB $1 * 07 A P A, * 11 W X E$ & AY877249, AY877250 \\
\hline NT00518 & $\begin{array}{l}\text { African- } \\
\text { American }\end{array}$ & $A * 3402,{ }^{*} 68 X X$ & $B * 1599, * 8101$ & $\mathrm{CW}^{*} 030402,0804$ & DRB1 *15JST, * 1001 & AY877255, AY877256 \\
\hline GN00360 & Caucasoid & $A^{*} 01,{ }^{*} 02$ & $B * \mathbf{2 7 0 5 0 7 , * 0 8 0 1}$ & $\begin{array}{l}\text { CW*020202, } \\
{ }^{*} 07 \text { WTR }\end{array}$ & NT & $\begin{array}{l}\text { AF266521 }{ }^{\mathrm{e}}, \text { AF266522, } \\
\text { AY700219 }\end{array}$ \\
\hline NT00514 & Caucasoid & $A^{*} 01 X X,{ }^{*} 680101$ & $B * \mathbf{2 7 2 8}, * 08 D K G$ & NT & DRB $1 * 03 \mathrm{KAJ}, * 13 \mathrm{KBC}$ & AY877253, AY877254 \\
\hline NT00573 & $\begin{array}{l}\text { African- } \\
\text { American }\end{array}$ & $A^{*} 02 A D V V,{ }^{*} 02$ VFS & $B * 350104, * 530101$ & $\mathrm{CW}^{*} 04 \mathrm{ZFD}, * 1601$ & DRB1 ${ }^{*} 07 \mathrm{APA},{ }^{*} 08 \mathrm{CKE}$ & DQ007039, DQ007040 \\
\hline NT00565 & Unknown & $A^{*} 68$ & $B * 3558, * 3521$ & $\mathrm{CW}^{*} 04 \mathrm{KGB}$ & DRB $1{ }^{*} 04 Y_{K},{ }^{*}$ 04DJX & AY907708, AY907709 \\
\hline NT00566 & $\begin{array}{l}\text { American- } \\
\text { Indian }\end{array}$ & $A * 24 A G \cup G,{ }^{*} 26 S T B$ & $B * \mathbf{3 8 1 1}, * 390602$ & $\mathrm{CW}^{*} 07 \mathrm{BJ},{ }^{*} 12 \mathrm{NP}$ & DRB $1{ }^{*} 04 \mathrm{ADJ},{ }^{*} 14 \mathrm{ACZ}$ & AY956752, AY956753 \\
\hline NT00509 & Unknown & $A^{*} 02 \mathrm{GNF},{ }^{*} 030101$ & $B * 3931, * 2702$ & $\begin{array}{l}\mathrm{CW}^{*} 020202 \\
* 120301\end{array}$ & $\begin{array}{l}\text { DRB1*110101, } \\
* 070101\end{array}$ & AY607032, AY607033 \\
\hline BY00055 & Caucasoid & $A^{*} 03$ & $B * 3932, * 1801$ & $\mathrm{CW}^{*} 0501 / 03,{ }^{*} 0702$ & $\mathrm{DRB} 1{ }^{*} 03,{ }^{*} 04$ & AY607030, AY607031 \\
\hline GN00423 & Unknown & $A * 24$ & $B * \mathbf{4 0 4 5}, * 1535$ & $\begin{array}{l}\mathrm{CW}^{*} 030401 / 03 \\
{ }^{*} 0702\end{array}$ & $\mathrm{DRB} 1 * 12, * 14$ & AY178187, AY178188 \\
\hline NT00568 & Unknown & A*68AEBA, *6901 & $B * 4107, * 1504$ & $\mathrm{CW}^{*} 010201,17 \mathrm{MN}$ & DRB1*07MT, *14BF & AY935260, AY935261 \\
\hline BY00048 & Unknown & $\begin{array}{l}\text { A*02PSD, }^{*} \text { *030101G1/0308 }\end{array}$ & $\begin{array}{l}B * 420501 \\
* 400101\end{array}$ & NT & DRB1*150101， *0404 & AY217666, AY217667 \\
\hline NT00521 & $\begin{array}{l}\text { Caucasoid- } \\
\text { Hispanic }\end{array}$ & $\mathrm{A}^{*} 0222,{ }^{*} 29 \mathrm{MS}$ & $B * \mathbf{4 8 1 2}, * 13 A B$ & $\mathrm{CW}^{*} 0602,{ }^{*} 0803$ & DRB1 ${ }^{*} 07 \mathrm{MT},{ }^{*} 08 \mathrm{BYC}$ & AY874083, AY874084 \\
\hline NT00569 & Caucasoid & $\begin{array}{l}\text { A*02ARBS, } \\
{ }^{* 02 A R B T}\end{array}$ & $B * \mathbf{4 8 1 2}, * 3543$ & $\mathrm{CW}^{*} 01 \mathrm{AEV},{ }^{*} 08 \mathrm{CF}$ & DRB1*0901 & AY956750, AY956751 \\
\hline NT00525 & Oriental & $\mathrm{A}^{*} 02 \mathrm{XSG},{ }^{*} 11 \mathrm{XSH}$ & $B * 510106, * 5401$ & $\mathrm{CW}^{*} 01 \mathrm{TF},{ }^{*} 14 \mathrm{BC}$ & DRB1 ${ }^{*} 08 Y M J,{ }^{*} 1403$ & AY877251, AY877252 \\
\hline BY00104 & Caucasoid & $A^{*} 0101,{ }^{*} 0201$ & $B * 5520, * 150101$ & $\mathrm{CW}^{*} 0401,{ }^{*} 0701$ & DRB1 ${ }^{*} 0701,{ }^{*} 1302$ & AY504809, AY504810, \\
\hline NT00572 & Unknown & $\mathrm{A}^{*} 01 \mathrm{YAG},{ }^{*} 03 \mathrm{BKS}$ & $B * 5520, * 350101$ & 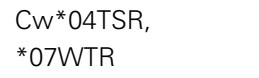 & DRB1 ${ }^{*} 01 \mathrm{RY},{ }^{*} 13 \mathrm{GPE}$ & DQ120786, DQ120787 \\
\hline NT00595 & Caucasoid & $\begin{array}{l}A^{*} 03 A D \\
A^{*} 29 W W P\end{array}$ & $\begin{array}{l}B * 5616 \\
* 15010101\end{array}$ & $\mathrm{CW}^{*} 01 \mathrm{BG},{ }^{*} 03 \mathrm{FJC}$ & DRB1*04NJV, *0901 & DQ0965573, DQ096574 \\
\hline
\end{tabular}

a HLA-A, -C, and -DRB1 were assigned primarily by probe-based typing. Letter codes indicate alternative alleles. The alleles included are described at the bioinformatics.nmdp.org web site.

${ }^{b}$ Novel allele is in bold type. The names have been officially assigned by the World Health Organization Nomenclature Committee (2). Alleles were assigned by DNA sequencing.

${ }^{c}$ Accession number of novel allele (exon 2 and exon 3 ).

${ }^{\mathrm{d}} \mathrm{NT}$, not tested.

e Accession number of novel allele (exon 1).

$\mathrm{CW}^{*} 0803$. $\mathrm{B} * 5520$ is a recombinant allele: the sequence of exons 1 and 2 is shared with $\mathrm{B}^{*} 550101$ and exon 3 with one nucleotide (and amino acid) substitution is shared with $B^{*} 4204$. Found in two cells, predicted haplotype carrying the new allele is $A^{*} 0101, B^{*} 5520$, DRB1*1302. Two haplotypes carrying new alleles are
A*3001, B*130202, Cw*0602, DRB1*0701,0703,0705,0707 and $A^{*} 30, B^{*} 1575$.

\section{Acknowledgments}

This research was supported by funding from the Office of Naval Research N00014-04-1-0398 and N00014-00-1-0898 
Table 2 Description of novel sequences

\begin{tabular}{|c|c|c|c|c|c|}
\hline Novel allele ${ }^{a}$ & $\begin{array}{l}\text { Most } \\
\text { homologous } \\
\text { allele }^{\text {b }}\end{array}$ & $\begin{array}{l}\text { Difference } \\
\text { (number of } \\
\text { nucleotides) }\end{array}$ & Codon changes $^{\mathrm{C}}$ & $\begin{array}{l}\text { Amino acid } \\
\text { changes }\end{array}$ & $\begin{array}{l}\text { Alternative nucleotide (amino acid substitution) } \\
\text { found at the altered codon and number of occurrences }{ }^{d}\end{array}$ \\
\hline$B^{*} 070204$ & $B^{*} 070201$ & 1 & 57 CCG to CCT & Silent & 57: CCG (P) 723, CGG (R) 1, CCA (P) 1, CCT (P) 1 \\
\hline \multirow[t]{4}{*}{$B^{*} 0738$} & \multirow[t]{4}{*}{$B^{*} 0727$} & \multirow[t]{4}{*}{5} & $67 \mathrm{TCC}$ to TTC & $67 \mathrm{~S}$ to $\mathrm{F}$ & 67: TCC (S) 303, TTC (F) 166, TAC (Y) 122, TGC (C) 105, ATG (M) 28, TCG (S) 2 \\
\hline & & & $77 \mathbf{G A C}$ to $\mathbf{A A C}$ & $77 \mathrm{D}$ to $\mathrm{N}$ & 77: AGC (S) 492, AAC (N) 197, GAC (D) 35, GGC (G) 1, TGC (C) 1 \\
\hline & & & $80 \mathrm{ACC}$ to $\mathrm{ATC}$ & $80 \mathrm{~T}$ to I & 80: AAC (N) 488, ATC (I) 119, ACC (T) 118, AAG (K) 1 \\
\hline & & & $81 \mathbf{C T G}$ to $\mathbf{G C G}$ & $81 \mathrm{~L}$ to $\mathrm{A}$ & 81: CTG (L) 534, GCG (A) 191, CCG (P) 1 \\
\hline$B * 0742$ & B*070201 & 1 & $181 \mathbf{C G C}$ to $\mathbf{A G C}$ & $181 \mathrm{R}$ to $\mathrm{S}$ & 181: CGC (R) 721, AGC (S) 1, CAC (H) 1 \\
\hline$B^{*} 0821$ & $B^{*} 0811$ & 2 & $163 \mathbf{G C G}$ to $\mathbf{C T G}$ & $163 A$ to $L$ & 163: CTG (L) 348, GAG (E) 197, ACG (T) 178, GCG (A) 1, GGG (G) 1, ATG (M) 1 \\
\hline$B^{*} 130202$ & $B * 130201$ & 1 & 39 GAC to GAT & 39 silent & 39: GAC (D) 724, AAC (N) 1, GAT (D) 1 \\
\hline$B^{*} 1312$ & $B * 1301$ & 1 & $163 \mathrm{GA} G$ to $\mathrm{G} \mathbf{G G}$ & $163 E$ to $G$ & 163: CTG (L) 348, GAG (E) 197, ACG (T) 178, GCG (A) 1, GGG (G) 1, ATG (M) 1 \\
\hline \multirow[t]{2}{*}{ B*1575 } & \multirow[t]{2}{*}{ B*150102 } & \multirow[t]{2}{*}{2} & $121 \mathrm{AAA}$ to $\mathrm{AAG}$ & 121 silent & 121: AAG (K) 659, AAA (K) 67 \\
\hline & & & $152 \mathbf{G A G}$ to $\mathbf{C A G}$ & $152 \mathrm{E}$ to $\mathrm{Q}$ & 152: GTG (V) 448, GAG (E) 274, GCG (A) 1, CAG (Q) 1, ACG (T) 1, GTC (V) 1 \\
\hline B*1598 & B*1503 & 1 & $43 \mathrm{CCG}$ to $\mathrm{CTG}$ & $43 \mathrm{P}$ to $\mathrm{L}$ & 43: CCG (P) 721, CTG (L) 2, CCA (P) 1, CAG (Q) 1, CCC (P) 1 \\
\hline$B^{*} 1599$ & $B * 1510$ & 1 & $156 \mathrm{CTG}$ to $\mathrm{CGG}$ & $156 L$ to $R$ & 156: CTG (L) 485, GAC (N) 94, CGG (R) 77, TGG (W) 69, GAA (E) 1 \\
\hline$B * 270507$ & B*270502 & 1 & $161 \mathrm{GAG}$ to GAA & 161 silent & 161: GAG (E) 725, GAA (E) 1 \\
\hline \multirow[t]{2}{*}{$B * 2728$} & \multirow[t]{2}{*}{$B * 270502$} & \multirow[t]{2}{*}{3} & $163 \mathbf{G A G}$ to $\mathbf{A C G}$ & $163 \mathrm{E}$ to $\mathrm{T}$ & 163: CTG (L) 348, GAG (E) 197, ACG (T) 178, GCG (A) 1, GGG (G) 1, ATG (M) 1 \\
\hline & & & $171 \mathrm{TAC}$ to $\mathbf{C A C}$ & $171 \mathrm{Y}$ to $\mathrm{H}$ & 171: TAC (Y) 631, CAC (H) 95 \\
\hline$B * 350104$ & B*350101 & 1 & 99 TAT to TAC & 99 silent & 99: TAC (Y) 399, TAT (Y) 302, TTT (F) 12, TCT (S) 12, TGC (C) 1 \\
\hline$B * 3558$ & $B * 3505$ & 1 & $152 \mathrm{GTG}$ to $\mathrm{GAG}$ & $152 \mathrm{~V}$ to $\mathrm{E}$ & 152: GTG (V) 448, GAG (E) 274, GCG (A) 1, CAG (Q) 1, ACG (T) 1, GTC (V) 1 \\
\hline$B * 3811$ & $B * 380101$ & 2 & 52 ATA to GTG & 52 I to $\mathrm{V}$ & 52: ATA (I) 715, GTG (V) 11 \\
\hline$B * 3931$ & $B * 39010101$ & 1 & 9 TAC to $\mathbf{C A C}$ & $9 \mathrm{Y}$ to $\mathrm{H}$ & 9: TAC (Y) 533, CAC (H) 164, GAC (D) 28 \\
\hline \multirow[t]{2}{*}{ B*3932 } & \multirow[t]{2}{*}{ B*39010101 } & \multirow[t]{2}{*}{3} & $163 \mathbf{A C G}$ to $\mathbf{C T G}$ & $163 \mathrm{~T}$ to $\mathrm{L}$ & 163: CTG (L) 348, GAG (E) 197, ACG (T) 178, GCG (A) 1, GGG (G) 1, ATG (M) 1 \\
\hline & & & $171 \mathbf{T A C}$ to $\mathbf{C A C}$ & $171 \mathrm{Y}$ to $\mathrm{H}$ & 171: TAC (Y) 631, CAC (H) 95 \\
\hline \multirow[t]{2}{*}{$B * 4045$} & \multirow[t]{2}{*}{$B * 400102$} & \multirow[t]{2}{*}{2} & $97 \mathrm{AG} \mathbf{G}$ to $A G \mathbf{C}$ & $97 \mathrm{R}$ to $\mathrm{S}$ & $\begin{array}{l}\text { 97: AGG (R) 398, AGC (S) 144, ACG (T) 125, AAT (N) 35, GTG (V) 15, } \\
\text { TGG (W) 8, ATG (M) } 1\end{array}$ \\
\hline & & & 147 TTG to TGG & $147 \mathrm{~L}$ to $\mathrm{W}$ & 147: TGG (W) 684, TTG (L) 42 \\
\hline$B^{*} 4107$ & $B^{*} 4101$ & 1 & $103 \mathbf{G T G}$ to $\mathbf{C T G}$ & $103 \mathrm{~V}$ to $\mathrm{L}$ & 103: GTG (V) 556, CTG (L) 169, ATG (M) 1 \\
\hline \multirow[t]{2}{*}{$B * 420501$} & \multirow[t]{2}{*}{$B * 420101$} & \multirow[t]{2}{*}{2} & $178 \mathrm{ACG}$ to $\mathrm{AAG}$ & $178 \mathrm{~T}$ to $\mathrm{K}$ & 178: ACG (T) 621, AAG (K) 102, ATG (M) 1 \\
\hline & & & 182 GCG to GCT & 182 silent & 182: GCG (A) 618, GCT (A) 102, TCT (S) 1 \\
\hline \multirow[t]{5}{*}{$B * 4812$} & \multirow[t]{5}{*}{$B^{*} 4801$} & \multirow[t]{5}{*}{5} & $131 \mathbf{C G C}$ to $\mathbf{A G C}$ & $131 \mathrm{R}$ to $\mathrm{S}$ & 131: AGC (S) 531, CGC (R) 195 \\
\hline & & & 135 GCC to GCG & 135 silent & 135: GCG (A) 534, GCC (A) 192 \\
\hline & & & 138 ACG to ACC & 138 silent & 138: ACC (T) 406, ACG (T) 317, ACA (T) 2, AAG (K) 1 \\
\hline & & & $143 \mathbf{T C C}$ to $\mathbf{A C C}$ & $143 \mathrm{~S}$ to $\mathrm{T}$ & 143: ACC (T) 680, TCC (S) 44, ACT (T) 1, ATC (I) 1 \\
\hline & & & 147 TTG to TGG & $147 \mathrm{~L}$ to $\mathrm{W}$ & 147: TGG (W) 684, TTG (L) 42 \\
\hline$B * 510106$ & $B * 510101$ & 1 & 69 ACC to ACT & 69 silent & 69: ACC (T) 548, GCC (A) 165, CGC (R) 10, GGC (G) 1, ACT (T) 1, ATC (I) 1 \\
\hline \multirow[t]{5}{*}{ B*5520 } & \multirow[t]{5}{*}{$B * 4204$} & \multirow[t]{5}{*}{5} & $11 \mathbf{T C C}$ to $\mathbf{G C C}$ & $11 \mathrm{~S}$ to $\mathrm{A}$ & 11: GCC (A) 493, TCC (S) 230, GCT (A) 2 \\
\hline & & & $12 \mathbf{G T G}$ to $\mathbf{A T G}$ & $12 \mathrm{~V}$ to $\mathrm{M}$ & 12: ATG (M) 483, GTG (V) 242 \\
\hline & & & 24 TCA to $\mathbf{G C A}$ & $24 \mathrm{~S}$ to $\mathrm{A}$ & 24: GCA (A) 305, TCA (S) 224, ACC (T) 194, TCC (S) 1, CCC (P) 1 \\
\hline & & & $31 \mathrm{ACC}$ to $\mathrm{ACG}$ & 31 silent & 31: ACC (T) 374, ACG (T) 351 \\
\hline & & & $103 \mathbf{G T G}$ to $\mathbf{C T G}$ & $103 \mathrm{~V}$ to $\mathrm{L}$ & 103: GTG (V) 556, CTG (L) 169, ATG (M) 1 \\
\hline$B * 5616$ & $B * 5601$ & 1 & $24 \mathbf{G C A}$ to $\mathbf{T C A}$ & $24 \mathrm{~A}$ to $\mathrm{S}$ & 24: GCA (A) 305, TCA (S) 224, ACC (T) 194, TCC (S) 1, CCC (P) 1 \\
\hline
\end{tabular}

a Exons 2 and 3 of the human leukocyte antigen (HLA)-B alleles were characterized by DNA sequencing. In some cases, the HLA-B alleles were amplified separately from genomic DNA with group-specific HLA-B primers and identified using sequence-based typing as previously described $(3,4)$. The polymerase chain reaction (PCR)-amplified HLA-B alleles in these samples were sequenced using an ABI Prism Big Dye ${ }^{\mathrm{TM}}$ Terminator Cycle Sequencing Ready Reaction kit and a 3730 xl sequencer (Applied Biosystems, Foster City, CA, USA). Amplicons from samples with a novel allele that could not be isolated individually by group-specific PCR were ligated into the pCR2.1-TOPO vector and cloned (HPT TOPO TA cloning kit, Invitrogen, Carlsbad, CA). Sequencing of several random bacterial colonies determined the sequence of the allele. Both the HLA-B alleles from a cell were also sequenced together using previously described primers by our group $(3)$ and $(4,5)$ to provide an additional confirmation of the two alleles present.

${ }^{b}$ Most homologous sequence obtained from IMGT/HLA sequence database (www.ebi.ac.uk/imgt/hla/).

${ }^{c}$ Numbering from the first codon of the mature protein. The altered codon(s) number and sequence of the most homologous allele compared with the novel allele is listed second. The nucleotide change(s) is in bold.

${ }^{d}$ The alternative sequences present at the altered codon are listed with the number of occurrences. For example, allele $B^{*} 070204$ differs from $B * 070201$ at codon 57. At this codon, in all HLA-B alleles, nucleotide sequences are found: CCG encoding proline in $723 \mathrm{HLA}-\mathrm{B}$ alleles, CGG encoding arginine in one allele, CCA encoding proline in one allele, and CCT encoding proline in one allele. The sequence found in the novel allele is in bold. The information was obtained from IMGT/HLA sequence database release Version Report - 2.12 (01/2006) at www.ebi.ac.uk/imgt/hla/. 
to the C.W. Bill Young Marrow Donor Recruitment and Research Program. The views expressed in this article are those of the authors and do not reflect the official policy of the Department of the Navy, the Department of Defense, or the US government.

\section{References}

1. Cao K, Chopek M, Fernandez-Vina MA. High and intermediate resolution DNA typing systems for class I HLA-A, $\mathrm{B}, \mathrm{C}$ genes by hybridization with sequence-specific oligonucleotide probes (SSOP). American Red Cross, National
Histocompatibility Laboratory, Baltimore, Maryland 21201-1595, USA. Rev Immunogenet 1999: 1: 177-208.

2. Marsh SGE, Albert ED, Bodmer WF et al. Nomenclature for factors of the HLA system, 2005. Tissue Antigens 2005: 65: 301-68.

3. Steiner NK, Gans C, Baldassarre L et al. Twenty-five novel HLA-B alleles. Tissue Antigens 2003: 62: 263-6.

4. Cereb N, Yang SY. Dimorphic primers derived from intron 1 for use in the molecular typing of HLA-B alleles. Tissue Antigens 1997: 50: 74-6.

5. Cereb N, Maye P, Lee S, Kong Y, Yang SY. Locus-specific amplification of HLA class I genes from genomic DNA: locus-specific sequences in the first and third introns of HLA-A, -B, and -C alleles. Tissue Antigens 1995: 45: 1-11. 